\title{
Social Cohesion and Community Displacement in Armed Conflict Evidence from Palestinian Villages in the 1948 War
}

\author{
Daniel Arnon* Richard J. McAlexander ${ }^{\dagger} \quad$ Michael A. Rubin ${ }^{\ddagger}$
}

January 26, 2021

\begin{abstract}
Why do some communities flee their homes during armed conflict, while others remain and risk exposure to further violence? This article investigates whether and how whole communities flee home territory, which we refer to as evacuation, in the context of strategic displacement campaigns. We explain variation in the process of forced displacement, focusing on civilian agency in shaping conflict processes. Specifically, we differentiate between preemptive (prior to displacement violence) and violent (in response to displacement violence) evacuation. We theorize that, in the context of strategic displacement campaigns, social cohesion enhances communities' ability to preemptively evacuate by facilitating collective action to evade imminent violence exposure. We test the theory in the context of Arab Palestinian communities' displacement during the 1948 war in Mandate Palestine. We measure village evacuation drawing upon historical accounts of forced displacement during the war and social cohesion using an original dataset based on new archival material from a survey of Arab Palestinian villages conducted during the early 1940s.
\end{abstract}

\footnotetext{
*Emory University

${ }^{\dagger}$ University of Pennsylvania

‡University of Connecticut, Human Rights Institute. michael.a.rubin@uconn.edu.
} 


\section{Introduction}

Why do some communities flee their homes during armed conflict, while others remain and risk exposure to further violence? Predominant explanations for population displacement during conflict highlight factors that shape civilians' incentives whether to flee or remain; including the form and intensity of violence, economic and political conditions, identity attachments to home territory, and social or economic linkages to areas of refuge. Though important, these variables cannot account for substantial local-level variation in displacement patterns, in part because they limit the role civilian agency may play in shaping conflict processes.

This article contributes by emphasizing variation in civilians' capabilities to act upon these incentives. We argue that community social cohesion, by promoting collective action, represents an essential source of locallevel variation in population displacement during armed conflict. Furthermore, we draw attention to variation in the process of forced displacement. We explain variation in whether and how whole communities flee home territory, which we refer to as evacuation. We distinguish between preemptive and violent evacuation, based on whether the community flees prior, or in direct response, to displacement violence. Whether communities are able to flee preemptively makes a substantial difference in the number of casualties and the level of suffering in these vulnerable populations.

Our argument complements existing work emphasizing the role of incentives. Whether communities leverage social cohesion to mobilize collective flight, as opposed to resistance or other strategies to remain in place, depends on the intensity and form of violence they expect to encounter by remaining. With a greater risk of a massacre, civilians increasingly leverage social cohesion for collective flight rather than resistance, increasing the likelihood of preemptive evacuation. This article investigates community-level forced displacement in the context of ethnoterritorial competition; in which belligerents "seek to maximize the territory under control of their coethnics" (Wimmer and Miner 2020), often by adopting strategic displacement violence involving "intentional, systematic displacement of civilians" (Lichtenheld 2020, 256). Because of the heightened risk of massacre, civilians facing strategic displacement violence in ethnoterritorial conflict are especially likely to mobilize collective flight.

We test the argument empirically in the context of the 1948 War in Mandate Palestine: the war leading to Israel's statehood and the Arab Palestinian population's al-Nakba. In November 1947, the United Nations General Assembly approved Resolution 181, the UN Special Committee on Palestine (UNSCOP) plan to partition Palestine into separate Jewish and Arab territories. Arab Palestinian leadership had long opposed a partition solution and rejected the plan immediately. While the Jewish leadership formally accepted the plan, they had prepared for the military conflict they expected would inevitably result from their statebuilding 
efforts given the demographic reality of a large Arab Palestinian population in the land sought for the Jewish state. The Partition Plan thus precipitated an escalation from low-level violence to full-scale war in which each side sought to carve out territory to exercise self-determination, as well as a tactical shift towards strategic displacement violence. Israeli forces engaged in cleansing (Pappe 2007); "deliberate expulsion of members of a political, ethnic, or social group" with the intention to permanently displace the targeted population (Lichtenheld 2020, 256) ${ }^{1}$. These changes in the security environment increased Arab Palestinians' incentives to (preemptively) flee contested territory.

Despite Israeli offesives which resulted in the evacuation of over 400 villages during the course of the war, displacing over 700,000 individuals, over 80 villages remained in place and elected to surrender rather than flee. We measure variation in Arab Palestinian communities' evacuation during the war by drawing upon detailed historical accounts of villages that suffered forced displacement (Khalidi and Elmusa 1992; Morris 1987). Though a central part of the historical scholarship, to our knowledge this article is the first to leverage these sources for systematic (quantitative or qualitative) hypothesis testing of generalizable social science theories. To measure social cohesion and other predictors of community evacuation, we draw upon new data extracted from the "Village Files": a village-level survey of Arab Palestinian communities conducted by the Haganah, the main Jewish military organization that would form the core of the Israeli Defense Forces, in the early 1940s. ${ }^{2}$ The full dataset includes 562 Arab villages. Israeli forces did not contest areas in the West Bank and southern Gaza, so we exclude them from the sample. We also exclude temporary villages (Khirbe), nomadic Bedouin communities, and Jewish-majority villages, leaving 249 villages in the sample analyzed below.

The 1948 war poses a hard test for the role of civilian agency in displacement processes. Because armed belligerents possess the capacity to deploy organized violence to control non-combatants, civilian agency plays a greater role in contexts in which the belligerent's primary objective with respect to the population is to limit civilian defections, rather than to kill or displace a population perceived as hostile to their ultimate

\footnotetext{
${ }^{1}$ While expulsions and cleansing operations occurred, Benny Morris demonstrates that these policies were far from uniform across regions and operations. For example, during the last major Israeli offensive, for the first time planned and executed through a clear military hierarchy, cleansed the southern areas of all Arab inhabitants while the simultaneous operation in the upper Galilee left over 60,000 Arab Palestinian residents in their homes. Morris concludes that the lack of uniformity in evacuation, even in villages which experienced massacres (for example - Majd al Kurum, Bi'na, Deir al Assad), indicates that while strategic displacement occurred, cleansing was not uniformly the goal of Israeli operations. Nonetheless, the fear of their recurrence was a strong driver of Palestinian displacement

${ }^{2}$ These data were collected by the perpetrator of strategic displacement violence that generated the variation in community forced displacement under examination. This raises ethical and measurement bias issues, both of which we discuss below and in the supplementary appendix.
} 
political or military goals (Kaplan 2017, pg. 11). Given Israeli forces' strategic displacement operations, predominant existing arguments imply that, in this case, variation in community displacement should be largely explained by strategic violence. Nevertheless, we show local-level variation cannot be fully explained by these factors, and illustrate an explanatory role for community social cohesion.

Because of its unique characteristics, scholars have rarely investigated the 1948 war as a case to test general social science theories. However, deeper investigation suggests some supposed idiosyncrasies are less pronounced than broadly perceived, and that there are sufficient parallels to other cases to permit measured generalizations from examining the case. Though the Jewish and Arab Palestinian movements were unique in important ways, the core dynamics of ethnoterritorial competition is a common feature in ethnic, especially homeland, conflicts as well as anti-colonial struggles between indigenous and settler populations. Pappe (2007), for example, explicitly compares Israeli violence in the 1948 war to Serbia's ethnic cleansing campaign in Kosovo.

In addition to theory testing, the empirical analysis provides new descriptive insights into the history of the 1948 War and its aftermath. Our focus on civilian agency in displacement processes, and the communitylevel variation, departs from the dominant narratives of the Israel-Palestinian conflict, which have focused on either Israeli forces' victimization or Palestinian elites' intentional and unintentional actions that encouraged Arab Palestinians to leave their homes. Furthermore, the Village Files have received only limited attention from social science scholars, having been under embargo. We negotiated access to the files in the Haganah Archives, translated them from the original Hebrew, and developed a coding scheme to operationalize the information in each village assessment. By making the original documents and their translated versions publicly accessible, we hope other scholars will incorporate these sources into future research.

\section{Concepts and Measurement}

\subsection{Preemptive and Violent Evacuation}

Community evacuation represents a specific manifestation of forced displacement in which the entire community leaves their home territory. We distinguish between two different evacuation processes. Preemptive evacuation occurs when the community flees prior to strategic displacement violence, whereas violent evacuation occurs in response to direct exposure to said violence.

We adopt the term evacuation to highlight two critical features of the outcome under investigation. First, we focus on the civilian community's actions that shape variation in population displacement. We therefore distinguish from familiar concepts such as cleansing or depopulation, which are generally used to describe a 


\section{Palestinian Villages}

- Preemptive Evacuation

- No Evacuation

- Violent Evacuation

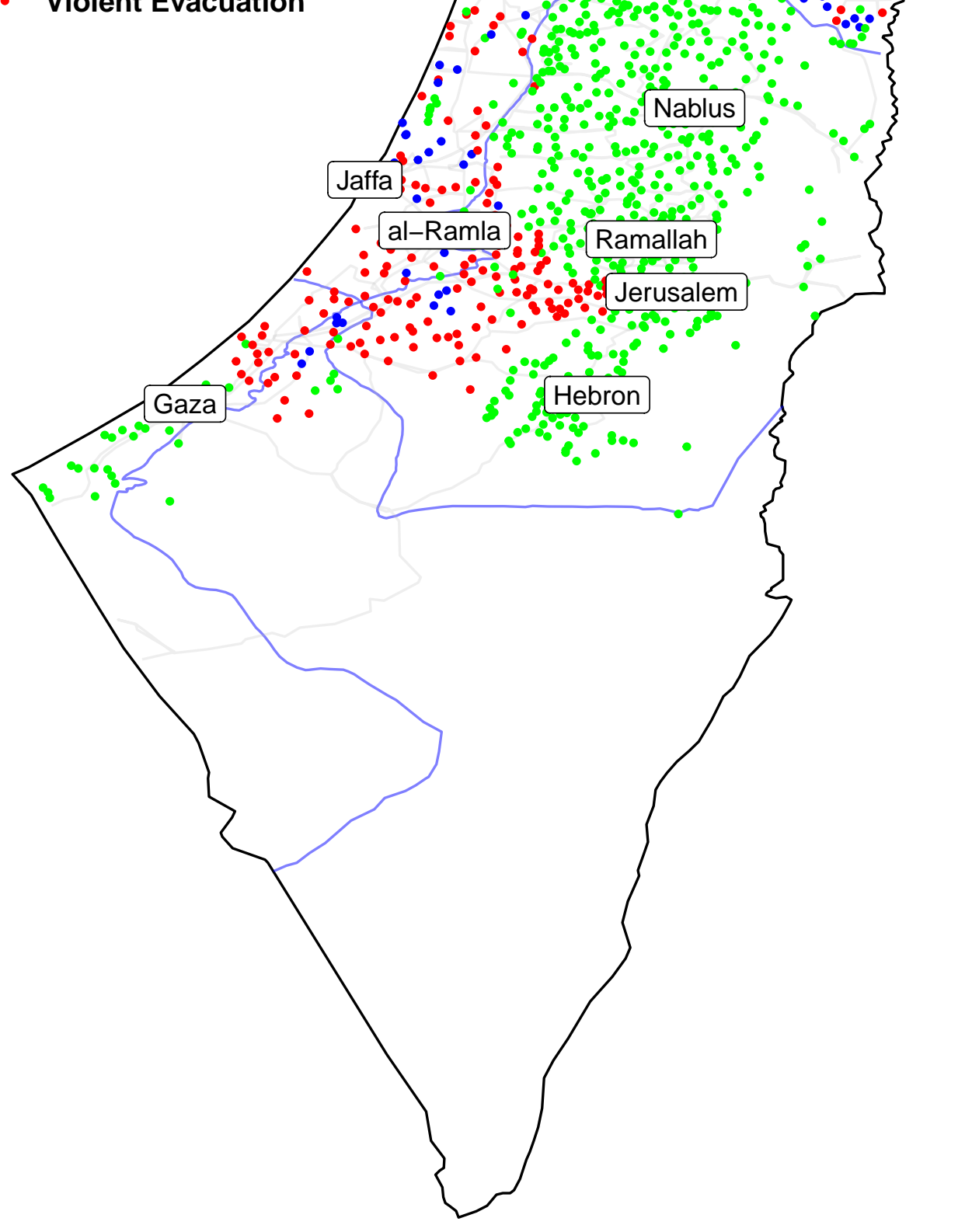

Figure 1: The map shows the location of villages in Mandate Palestine in 1948. Blue villages are villages that experience preemptive evacuation, green villages are 4 illages that experience no evacuation, and red villages are villages that experienced violent evacuation. The blue line is the partition plan. Note that in many cases, villages in proximity to one another yielded different evacuation outcomes despite similar threats of violence exposure. 
perpetrator's actions that generate displacement and civilian casualties, thus de-emphasizing civilian agency. Like these concepts, evacuation implies forced displacement, including as a response to these and other forms of violence. The main distinction is the attention to civilian behavior, which is not a mechanical reaction to violence but a variable of interest in its own right. Evacuation does not imply an intention to permanently leave home territory. As was the case for many during the Israeli offensive in 1948, civilians may evacuate to escape violence with the intention of returning once the violence has subsided.

Second, we distinguish from collective flight, migration, and similar terms that do not necessarily imply complete evacuation. We focus on complete evacuation not because partial depopulation is inconsequential, but because the historical record in the case under investigation is clearer on distinguishing villages that were completely depopulated from those that were not than it is on distinguishing partially depopulated from those that remained intact. We measure whether an evacuation event occurred, and if so the type (preemptive or violent), by drawing upon in-depth historical investigations conducted by Morris (1987) and Khalidi and Elmusa (1992), which provide a census of completely depopulated villages. This variation is of clear importance even if it does not characterize the full range of conflict displacement.

Figure 1 maps the three potential evacuation outcomes in Arab Palestinian villages during the 1948 War: 1) preemptive evacuation, 2) violent evacuation, and 3) no evacuation. Where no evacuation occurs, this does not imply the absence of forced displacement; only that a substantial portion of the community remains within the home territory and that the village continued to exist with (at least some of) its pre1948 inhabitants. The sea of "no evacuation" villages in the eastern and north-central portions of the map (nowadays referred to as the West Bank) and southwest (southern Gaza), as noted, are excluded from analysis because Israeli forces did not contest them during the 1948 war. After May 15th, the Israelis crossed the UN Partition line specifically to conquer Jerusalem, areas of the northern Galilee, northern Gaza in the southwest and the southern Naqab/Negev. While strategic military considerations can explain the cluster of violently evacuated villages near Jerusalem, which was of immense cultural and strategic importance to both sides, they cannot fully account for displacement patterns within and across the rest of the country. Note that in many cases, villages in proximity to one another yielded different evacuation outcomes despite similar threats of violence exposure. This article aims to explain this puzzling variation.

\subsection{Social Cohesion and the Village Files}

Social cohesion refers to both individual- and group-level characteristics. At the individual level, social cohesion encompasses "(a) individuals' membership attitudes (their desire or intention to remain in a group, their identification with or loyalty to a group, and other attitudes about the group or its members); and 
(b) individuals' membership behaviors (their decisions to sever, weaken, maintain, or strengthen their membership or participation in a group, their susceptibilities to interpersonal influence, and other behavioral indicators of commitment and attachment to the group)" (Friedkin 2004, 410). At the group level, social cohesion refers to the distribution of these membership attitudes and behaviors in the relevant population (Friedkin 2004). Group-level social cohesion is related to the cognate concept of social capital, "the norms and networks that enable people to act collectively" (Woolcock and Narayan 2000, 226).

Individuals retain membership and identity attachments to multiple, overlapping, social groups simultaneously. Community social cohesion, specifically, implies the distribution of residents' attitudes and behaviors relevant to the community, participation in community activities, and commitment to community welfare. Armed conflict and violence often strain the complementarity between overlapping social identities, for example by pitting community membership against parochial group identities, such as clan or family. Therefore, to observe variation in the degree of community social cohesion, one must assess residents' attitudes and behaviors with respect to the community in comparison to attitudes and behaviors with respect to these parochial identities.

We measure Arab Palestinian communities' social cohesion by drawing upon archival documents that record information on social, political, and economic conditions within Arab Palestinian villages during the years preceding the 1948 War. The Haganah's Information Services (Shai) compiled what is commonly known as the "Village Files" in the early-to-mid 1940s. The information recorded in these files is rich and detailed, since it draws upon informant residents within each village and scouting missions. Ezra Danin, the project's leader, composed a uniform questionnaire to ensure that the information was collected systematically. ${ }^{3}$

The Village Files include information about each hamula (hereafter, clan) in a village, which represents a primary social group through which members organize social, economic and political activity. The documents record clan size, religion and ethnic makeup, political affiliations with the rival Palestinian national movements, and, crucially, the existence of any rivalries or blood feuds between them. To measure social cohesion we aggregate these characteristics, which represent common social cleavages and barriers to social cohesion, within Arab Palestinian communities during this period. Figure 2 maps the bivariate relationship between social cohesion and evacuation outcomes within the sample included in the empirical analysis.

It is important to emphasize that our main archival source on social cohesion variables comes from the belligerent's intelligence reports, collected between periods of active hostilities and in preparation for the expected war. While this source may be biased, we have good reasons to use the information provided in these sources nonetheless. The main value of these documents is threefold. First, a small sample of the

\footnotetext{
${ }^{3}$ In the appendix we include the 30-item questionnaire and a translated file for Qira, in the Haifa subdistrict.
} 


\section{Community Evacuation and Social Cohesion}

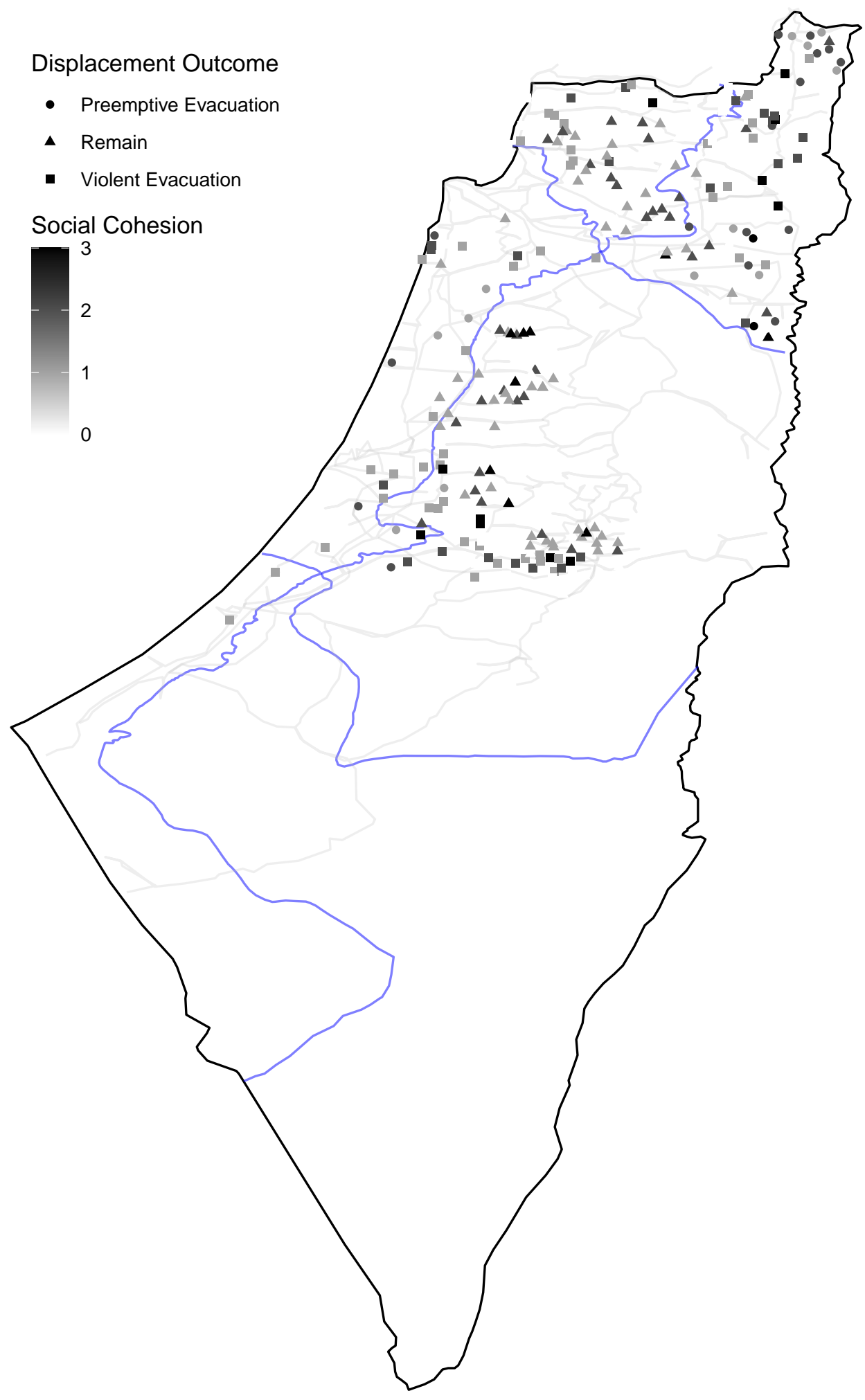

Figure 2: This map shows Arab Palestinian villages along with their displacement outcome and level of social cohesion. Darker villages indicate higher social ${ }^{7}$ cohesion, while the shape of the village icon indicates the type of displacement outcome. Note that the sample of villages changed from Figure 1 to include only relevant villages for this paper. 
information provided in them has been cross-referenced with other sources by the authors and others, and find it to be highly accurate (Abbasi 2019; Jawad 2016; Sela 2013) ${ }^{4}$. The second reason is that while the information collected in the village files was used in a few occasions, Salomon (the deputy chief archivist of the Haganah Archives) notes that they were not used systematically during the war, primarily because Israeli forces couldn't get them to frontline operations in time (Salomon 2010, 295). The third reason is the lack of contemporary Palestinian information about Palestinian village life at the time. As Meron Benvenishti notes, while the Village Files may be a problematic source of information on Palestinian life, their significance lies in our necessary reliance on "Jewish and British sources of information in the absence of Palestinian sources, in order to expand knowledge about Palestinians" (Benvenisti 2000, 78-79). Jawad similarly notes that "The Village Files survey, which was intended to destroy Palestinian society, has become, although it certainly was not the intention of those who designed the project, a historical source for the study of economic and social Palestinian history" (Jawad 2016, 33).

\section{How Community Social Cohesion Influences Evacuation during Armed Conflict}

This article explains variation in community evacuation in the context of violent ethnoterritorial conflict. Our general theoretical framework, summarized in Figure 3, considers an interaction between two actors, the community (C) and belligerent (B), in two stages. The first stage, pre-occupation, describes the period before belligerent forces attempt to occupy the community's home territory. The second stage, occupation, begins when belligerent forces occupy the territory. The interaction yields three potential outcomes: 1) preemptive evacuation, 2) violent evacuation, or 3) no evacuation.

The pre-occupation period does not imply the absence of violence: in addition to violence in the broader conflict zone, the community may suffer communal violence or other forms of belligerent violence that do not yet constitute strategic displacement. In the 1948 war, for example, Jewish and Arab armed factions routinely attacked non-coethnic communities in contested areas throughout the Mandate, and escalated in anticipation of British abdication from the Mandate. Pre-occupation is distinguished by the form of violence: the community has yet to experience strategic displacement violence, specifically. In this stage, the community makes a decision whether to collectively exit or not. Collective exit encompassing the whole community, if successful, terminates the process in preemptive evacuation. Communities in which only a subset of the population participates in collective exit do not constitute preemptive evacuation.

\footnotetext{
${ }^{4}$ The information on cross-references and validation of the information for a small sample is in the appendix
} 
If the community foregoes collective exit, or fails to mobilize evacuation in advance, then a substantial portion of the population remains in the occupation stage. Belligerents may use a variety of tactics to maximize coethnic control. We focus on variation in the intensity of strategic displacement violence, which ranges from none to mass killing. The occupation stage ends with either the community's violent evacuation or with at least some portion of the community remaining in the home territory, with the probability of violent evacuation increasing in the intensity of strategic displacement violence. To be clear, both of these potential outcomes may include civilian casualties, depending on the belligerent's use of violence.

Figure 3: Evacuation Process and Outcomes
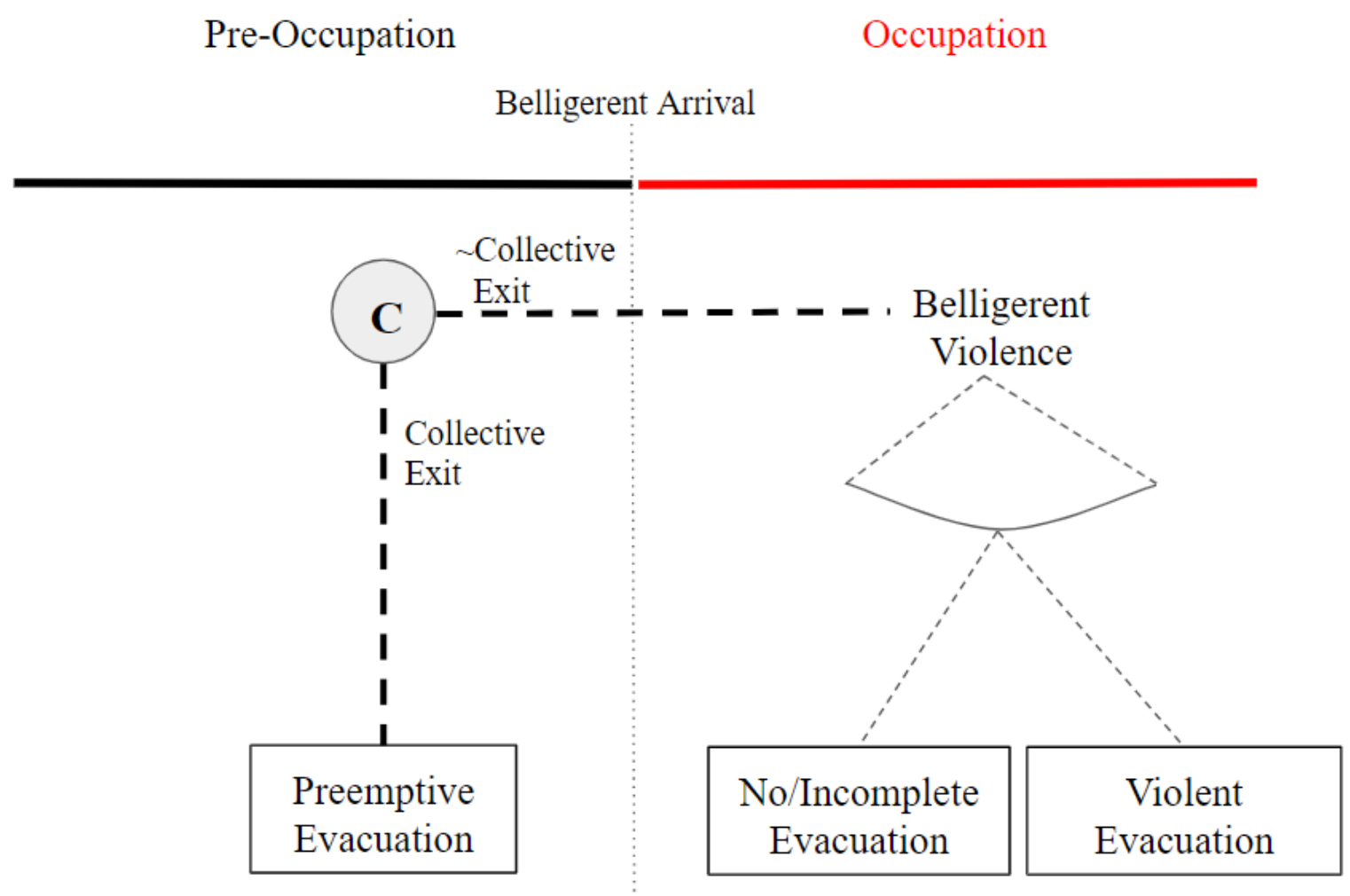

This article focuses on the first stage. Rather than accounting for the full variation across the three potential outcomes in the general framework, we explain variation in a binary outcome: whether the community successfully evacuates preemptively or remains through transition to occupation. This is the logical first step. Explaining variation in whether occupied communities are violently expelled requires understanding selection into which communities remain to be occupied. We leave investigating the subsequent interaction in the occupation stage for future research.

Community expectations of the level and form of violence in the occupation stage influence pre-occupation by increasing the incentive to flee contested territory. Nevertheless, expected violence does not fully account for local-level variation in preemptive evacuation because it cannot explain why some villages under simi- 
lar threat evacuate while others do not. We advance a complementary mechanism highlighting community capability to mobilize collective flight, thereby emphasizing the role of civilian agency in conflict and displacement processes. Social cohesion affects the community's capabilities to act collectively through two channels. First, cohesion increases efficiency of communication throughout the community to yield common information about the risks of future violence and others' likely behavior. Second, social cohesion generates, and reflects, the organizational infrastructure required to efficiently mobilize collective action.

\subsection{Community Actors}

Community members' primary interest is in survival, but they also have a strong secondary interest to remain in their homes. This implies that, facing a sufficiently high threat of strategic displacement violence, they are willing to flee. However, they may also be willing to accept some risk of bodily harm in order to remain in their homes through conflict violence. As the risk of lethal displacement violence grows, the survival imperative increasingly supersedes the interest in remaining in place.

All else equal, community members prefer collective rather than uncoordinated individual action. Clearly, when remaining in home territory to resist belligerent occupation, individuals share a preference for more of their neighbors to remain, in order to enhance their personal security and the efficacy of resistance. Crucial to our inquiry, existing research also suggests that, when civilians do consider fleeing, they have incentives to flee and resettle collectively.

Fleeing a conflict zone is, itself, a dangerous endeavor. Collective flight yields a higher survival rate, and, because of this, has a cascading effect by which more community members leaving the home territory makes additional individuals willing to flee (Camarena n.d.). Retaining one's community, and the social support it entails, through the stages of forced migration and subsequent displacement reduces individuals' costs associated with fleeing their homes, as they retain the social connections and bonds needed to rebuild physical and economic security in a new setting. Kaplan (2017, 44) notes that collective exit generates conditions such that "families can be kept together... in a safer location that is ready with supplies and assistance from neighbors." Furthermore, individuals considering flight may fear future conflict with those who remain upon returning after violence has subsided (Schwartz 2019). Collective flight and resettlement may be helpful in "facilitating a more rapid and orderly return to the territory if and when conflict conditions improve" (Kaplan 2017, 44), softening the downsides associated with fleeing conflict-affected territory.

Steele (2019) argues that civilians facing political cleansing maximize their security by clustering in geographic space, whether within the country (segregation) or across international borders (expulsion), which incentivizes collective exit. Displacement ruptures support networks underlying individuals' social safety net 
upon which they may depend to manage social and economic crises. Though collective exit may increase the risk that the group as a whole is targeted again, each individual has a lower probability of being targeted with violence compared to the alternative in which they resettle alone because they are easily identifiable for selective targeting (Steele 2019, 34). Indeed, in the Palestinian case under investigation below, villages were relocated largely intact within the refugee camp to which they fled (Khalili 2004).

Individuals and communities vary in their access to information regarding the level of threat posed by belligerent violence in their specific location at any given time. Civilians are uncertain about whether belligerents will actually occupy their specific location, the level and form of violence and property destruction occupation will entail, and the duration of active fighting. They cannot know which belligerent will control the area after the fighting stops, what the political order will look like, or the economic opportunities available. They are also uncertain how many of their fellow community members will stay versus flee. Should they decide to flee the home territory, civilians are uncertain about political conditions and economic opportunities available in possible areas of refuge, and how long they will need to remain displaced before they can return to their homes.

With perfect information about the level of violence in their area, civilians would flee only if and when an unbearable level of violence becomes imminent. The problem is, given these sources of uncertainty, individuals and communities must resolve these information gaps, and urgently, to ensure their survival while maximizing their chances of remaining in place. As we argue below, social cohesion plays an important role in reducing uncertainty to coordinate beliefs about the threat of violence, and facilitated collective action in response.

\subsection{The Effect of Violence on Displacement, and its Limitations}

A robust literature supports the premise that political violence substantially drives displacement processes. At the macro-level, the expected intensity (Davenport, Moore, and Poe 2003; Moore and Shellman 2004) and the form (Kalyvas 2006; Lischer 2007; Moore and Shellman 2006) of civilian-targeted violence, as well as the state's history of repression (Moore and Shellman 2007; Neumayer 2005b), each encourage vulnerable populations to flee. At the meso-level, displacement corresponds to subnational variation in belligerents' military capabilities, strategic interests in specific pieces of contested territory, and therefore the scale and form of violence (Balcells 2010, 2017; Kalyvas 2006; Schon 2015; Steele 2011, 2017 ; Wood 2010, 2014; Zhukov 2015). Belligerents are more likely to use strategic displacement violence in areas where they lack the capacity to identify and selectively target enemies, such that violence to control or expel the population is preferred to winning hearts and minds (Balcells 2010, 2017; Kalyvas 2006; Wimmer and Miner 2020; Zhukov 
2015). Furthermore, civilian communities' perceptions of the local balance of power matter. Revkin (2020) finds that a sizable majority of Mosul residents at the time of Islamic State takeover believed IS would lose control within weeks, in stark contrast to its three-year occupation of the city, which led many to remain in the area rather than flee.

Nevertheless, violence does not entirely explain this variation, and existing literature exposes a variety of factors that augment violence as a predictor of displacement. Political authorities in areas of refuge may vary in their treatment of displaced persons, and in their ability to absorb them into the economy. Therefore, as the security, political, and economic conditions in neighboring or other destination countries improve, civilians' willingness to seek refuge across borders may increase (Davenport, Moore, and Poe 2003; Neumayer 2004, 2005b, 2005a). Aside from government policy, sudden migration may stimulate anti-refugee/migrant backlash in host communities, which reduce individuals' prospects associated with the exit option (Getmansky, Sinmazdemir, and Zeitzoff 2018). Civilians may face disincentives to flee, even from active conflict zones. In addition to becoming stateless, migrants lack the knowledge and access to political channels in their new country. Social ties among community members at home may be broken or transformed in the process of migration, and power structures disintegrate or take on new meaning.

Furthermore, civilians are not passive victims reacting to circumstances, but rather strategically take actions to shape conflict and displacement processes. Though belligerents typically enjoy a decisive military advantage over civilians, communities that possess the (perceived) ability to influence belligerent conduct may be more likely to remain in home territory, expecting to leverage this power to shape the local political order under belligerent presence (Arjona 2016; Kaplan 2017; Rubin 2020). Even where they lack capacity to influence belligerent behavior, civilians may (rationally) choose to remain in their homes despite violence (Engel and Ibáñez 2007; Melander and Öberg 2006; Steele 2009). Individuals may possess identity attachments to their home territory, strong economic incentives (Adhikari 2013; Czaika and Kis-Katos 2009; Engel and Ibáñez 2007), or social connections that reduce their security risks in the home territory (Marston 2020). This article contributes by complementing the existing emphasis on civilian incentives with attention to variation in community capabilities to act collectively to pursue shared interests.

\subsection{Social Cohesion Enhances Collective Action in the Fog of War}

Expected violence cannot fully account for variation in whether communities flee preemptively in the preoccupation stage for two main reasons. First, in the "fog of war," civilians possess limited information, which makes ex ante predictions about the risk of violence, and their fellow community members' actions, imperfect. Second, even with greater certainty, communities vary in their abilities to mobilize collective action to resist 
or evade belligerent occupation, as the circumstances dictate. Social cohesion plays an important role in conflict and displacement processes by mitigating each of these challenges.

Cohesion enhances generalized and interpersonal trust and strengthens communication networks needed to disseminate information (Chwe 1999; Gould 1993; Jackson, Rodriguez-Barraquer, and Tan 2012; Siegel 2009), including in conflict settings (Larson and Lewis 2018; Lewis 2017, 2020). As a result, information travels, and expectations of others' reciprocal pro-social behavior converge, more efficiently and encompass a larger portion of the population. Social cohesion increases a community's ability to build a broad consensus and to mobilize towards higher rates of participation in a variety of forms of collective action to protect community security; from active resistance against more powerful belligerents to mobilizing collective flight from areas of violence (Arjona 2016; Dorff 2017; Gade 2020; Kaplan 2017; Krause 2018; Parkinson 2013; Petersen 2001; Rubin 2020). Regarding collective flight, Steele (2017) shows how social networks within and across communities hasten the spread of information about belligerent movements, giving communities the opportunity to flee before belligerents arrive. Camarena (n.d.) emphasizes civilians' communication through social connections to reduce uncertainty in violent contexts and mobilize collective exit. Furthermore, socially cohesive communities have deeper experience with cooperation across social cleavage lines to resolve problems or achieve common goals. Inclusive institutions provide an infrastructure for mobilizing efficient and effective collective action. Owing to these positive associations with the community individuals may have otherregarding preferences that make them more willing to engage in costly activities for common benefit.

These direct effects of social cohesion on community action during conflict are insufficient, on their own, to predict displacement outcomes. Social cohesion and collective action simultaneously strengthen the community's ability to mobilize collective exit and the collective resistance or autonomy strategies in order to preserve the community in home territory. To explain variation in community-level evacuation requires taking into account the community's expected level of violence in the occupation stage. The risk of massacre influences the community incentives for collective exit or resistance, and community cohesion influences the variation in the likelihood of successful mobilization in the selected strategy.

\subsection{Social Cohesion and Preemptive Evacuation in Strategic Displacement Campaigns}

When the expected costs associated with occupation are sufficiently low, communities may leverage social cohesion to retain a strong presence in the home territory, which preserves community autonomy and security (Arjona 2016; Kaplan 2017). This condition may prevail when the belligerent actor's main objective is to prevent civilian defection, rather than to promote population displacement, especially when the actor's 
ultimate objective is to govern the local population in the post-conflict era. It also occurs in contexts in which the belligerent actor is reliant upon the local population for material support or population concealment to avoid enemy reprisals. Under these conditions, civilians retain a variety of strategies for dealing with belligerents in their territory; including cooperating with one belligerent over others, negotiating autonomy, and, in extreme cases, mobilizing violent or nonviolent resistance to belligerent forces (Kaplan 2017). Each of these alignment strategies requires communities effectively negotiate with belligerents and communicate credible commitments to take specific actions as a collective, and social cohesion strengthens their ability to do so.

In settings characterized by high costs associated with the occupation stage, by contrast, communities leverage social cohesion to mobilize collective exit to escape violence exposure and repression, resulting in a higher likelihood of preemptive evacuation in the pre-occupation stage. This condition prevails when the belligerent's main objective is to displace the local population in order to shift the demographic balance in favor of its core constituency, or has other primary objectives to holding the territory such as extracting lootable natural resources or controlling strategic routes for moving military personnel and supplies. These conditions lead communities to expect unbearably high costs of occupation especially when the belligerent need not rely on local compliance or support.

Under these conditions, social cohesion accounts for why some communities that attempt collective exit are able to achieve preemptive evacuation, while in others community members are exposed to violence. As described above, social cohesion increases the speed with which information spreads throughout the community to communicate the risk and converge on a collective response. Of course, uncertainty regarding the threat of violence is reduced by conflict processes external to the community; such as the occurrence of, and the community's proximity to, atrocities. Nevertheless, while proximity to displacement violence may reduce uncertainty and push the community to coordinate on collective exit over resistance, it also leaves little time to mobilize before exposure. Social cohesion also plays an important role in whether the community preemptively evacuates by enhancing the capacity to mobilize collective exit efficiently.

In this article, we focus on a context in which the expected costs of occupation are high. The legacy of political conflict and clashing Jewish and Arab national aspirations in Palestine throughout the British Mandate period, alongside deep attachment to the land (high stakes) among both Jews and Arabs, created a collision course toward violence. These conditions imply that Arab communities expected high costs associated with remaining in villages vulnerable to Jewish forces. These fears were reinforced, at least among the villages not yet occupied during the first offensive from April to May 1948, by some Israeli commanders' use of strategic displacement tactics. Therefore, our argument implies that in our sample, preemptive evacuation should be positively associated with community social cohesion. 
For certain community outcomes, such as preemptive evacuation, social cohesion is an essential component to collective action in large groups but not necessarily for small groups. In small communities, the barriers to communication, consensus building, and mobilization are low, regardless of the community's social and organizational infrastructure. There are simply few people to reach, impart information, and fewer veto points to achieving consensus. Furthermore, small groups may yield preemptive evacuation through mechanisms other than coordinated collective action.

Consider a purely non-cooperative cascade model in which each individual has a threshold value for the proportion of the community that has fled at which they decide to flee. In small communities, tipping point that triggers mass flight is a low number of community members, and the time from the first individual decision to flee until full evacuation is short. All else equal, the duration of the cascading process increases with the population, which leaves communities vulnerable to violence exposure in the interim. Social cohesion plays an essential role, closing this mobilization gap critical to preemptive evacuation, in large communities but not in small communities.

Hypothesis: In the 1948 War, the likelihood of preemptive evacuation increases in community social cohesion; especially among villages with larger population.

\section{Mandate Palestine and the 1948 War}

The transition to British colonial authority in Palestine following the First World War, replacing the crumbling Ottoman Empire, ushered in dramatic changes in Palestinian societies. The British recognized Jewish national rights - The Balfour Declaration in 1917-but did not do the same for Arab Palestinians. The influx of Jewish migration and organized land purchases significantly impacted social and economic conditions across social strata within the Arab Palestinian population: urban and rural; traditional elites and the nouveau riche; Christian, Muslim and Druze; sedentary and nomadic Bedouin. These incremental changes in dominant cleavages propelled the national Palestinian identity and transformed relations with the British and the Zionist-Jews.

Palestinian nationalist mobilization reached its apex in the revolt of 1936-1939. Though it enjoyed initial successes, pressuring the British to revoke Jewish immigration rights, overwhelming British force ultimately quashed the revolt. The titular leader during the early stages of the revolt, the Grand Mufti Amin alHusseini, fled to Lebanon. The national leadership and institutions essentially lost credibility among many Arab Palestinians, and the movement devolved into rabid infighting and fragmentation. Collaboration with Zionists, which was considered a treacherous act during the revolt, quickly became the norm after the revolt ended. By the mid-1940s Palestinian leaders were attempting to revive national institutions, but they 
remained fragmented and disparate. "A plethora of competing organizations and lack of central political leadership accepted by all became the most salient feature of Palestinian Arab politics" (Cohen 2009, pg. 208). By 1947 when the war erupted, Arab Palestinian communities had fragmented to such an extent that each community was left to fend for itself. Linkages between Arab Palestinian communities resisting Israeli statebuilding were rare, and weak (Al-Hout 1979; Khalaf 1991; Pearlman 2011).

By contrast, during the 1940s Zionists accelerated institutional statebuilding efforts and accumulated mat'eriel and military training in recognition of the inevitable confrontation with the Arab Palestinian population and the Arab states. The Zionists expanded military intelligence operations - including the survey of Arab Palestinian villages we use in the empirical section - through which the Haganah paramilitary forces obtained information from collaborators, Jewish scouts, and even former rebels, and in its later stages included aerial photographs and access points, though in the "fog of war" these were rarely used for operational purposes during the 1948 War. Large-scale illegal immigration operations were set up, smuggling in over 20,000 Jews by boats in defiance of the British white paper revoking Jewish immigration.

Ultimately, a sustained campaign of anti-colonial violence by the Zionists convinced British policymakers at home and in the colonial office that maintaining control over Palestine was more trouble than it was worth (Hoffman 2016). The British delegated this problem to the United Nations, who then created the UN Special Committee on Palestine (UNSCOP). UNSCOP entertained a number of options for how to deal with the ethnic conflict in Palestine, and in November 1947 ultimately decided to partition the Mandate into Jewish and Arab non-contiguous territories. Jewish-Zionist leaders accepted the UN plan, but Arab Palestinian leaders and Arab state leaders rejected it. Immediately after the UN announced the partition plan, Arab Palestinian attacks against Jews escalated in the ethnically mixed larger cities (Tal 2004), which quickly escalated to tit-for-tat exchanges between Jewish and Arab Palestinian militias. After the British withdrawal in May 1948, Arab state armies attacked the newly-founded state of Israel. Arab Palestinian communities, lacking national institutions to coordinate responses, relied on the invading Arab state forces to save them, but were eventually left to fend for themselves as these armies did not reach many of them.

\subsection{Israel's Strategic Considerations during the War}

The ensuing war that led to Israel's independence, and the Palestinian al-Nakba, is customarily divided into three parts, each with a major episode of forced displacement. In the first, November 1947 - February 1948, Jewish forces were mainly positioned defensively and the fighting is characterized by harassment and reprisal attacks between Jewish and local Arab Palestinian forces. By the end of February 1948, Jewish forces had begun adopting strategic displacement violence, expelling Arab Palestinians from their homes in contested 
territory, but this became more systematic with the adoption of Plan Dalet on March 10, 1948. Having secured strategic advantage over the local Arab Palestinian militias, in the second phase, March - October 1948, Jewish forces shifted to the offensive in anticipation of the British exit. This period included the the largest episode of forced displacement, primarily along strategic routes. By May 1948 neighboring Arab state forces began invading the areas of Mandatory Palestine, but failed to make inroads to protect Arab Palestinian communities. In the third phase, from November 1948 until the cessation of hostilities in March 1949, Israeli offensives continued and another round of forced displacement occurred.

During the offensives, the main areas of strategic concern for the Israeli forces were located along the main roads leading to areas of Jewish settlement. But, as Figure 1 shows, we still observe variation in whether villages were depopulated, and whether the village resisted or surrendered. Until April, most villages evacuated before the arrival of Jewish forces. Active expulsion policies began in earnest in April along the coastal plains, lower Galilee, and the Jerusalem corridor, though exceptions were made to multiple villages. Morris (1987 pg. 198) characterizes Israel's policy towards Arab villages on the main strategic routes as "inconsistent, circumstantial and haphazard."

It is important to note, that while a mass exodus occurred, over 130,000 individuals in 82 villages and three cities elected to surrender and remain under Israeli control. The high levels of fragmentation within Arab Palestinian society and the independent strategies that villages adopted, also led to variation in how they dealt with the Jewish forces, if and when they arrived, though we do not address this variation specifically in this article.

\subsection{Ethical Questions on the Use of the Village Files}

We emphasize that archival material is not a neutral source of information. They are themselves sites of "power, inequality, and erasure" that shape our knowledge and understanding (Luft 2020, 318). The Village Files are no exception. In fact, the politics of archival material continues to this day in Israel, with several public contestations of the censure of Israeli archival materials regarding the 1948 War and beyond (Pappé 2020; Raz 2021). The materials in the Village Files were made available to the authors during a short period of time in which these materials were open to the Israeli public before being digitized.

As with all data collected during periods of conflict, the Village Files enjoys distinct benefits and shortcomings. On one hand, these materials include contemporary and wide coverage of Palestinian life in the villages, which likely provides better coverage than data produced by monitors and from memory (Balcells and Sullivan 2018). They also provide a level of disaggretation, allowing for analysis at the smallest governance level in Mandate Palestine, and allows for examination of local level variation before the 1948 
War. Balcells and Sullivan further argue that archival sources, understood in their proper context, provide researchers with information they consider "closer to the ground truth of what transpired in a particular event" (Balcells and Sullivan 2018, 139).

But the Village Files are not absent of shortcomings as well. The information contained in the documents are given by the belligerent for future military purposes, and some may consider this information suspect with regard to Arab Palestinians social dynamics within a village. The information contained may be biased, for political purposes, or the product of the relationships between the surveying scouts and informants, given for purposes of retribution. Furthermore, the publication of censored files can serve political purposes in and of themselves. These files do not suffer from a politicized effect in their release, since their availability was not published to the Israeli public broadly, and were released only after the official Haganah Archivist had completed a ten year study of the documents, and releasing the "official history" of this archival material (Salomon 2010). In the following sections we also quantitatively explore possible biases in these data, comparing the distributions of the data, compared to the Statistical Survey in 1945.

Lastly, archival research also requires researchers to engage with ethical questions. The information discussed in the Village Files involves subjective information about relationships between clans within a village and includes information on people who would later be targeted for search-and-arrest operations, due to their involvement, allegedly, in the 1936-1939 revolt (Pappé 2006). As with administrative data collected by a state-in-the-making during conflict, the information was used for oppressive purposes even though their use was very limited during the war itself. As Subotic emphasizes, the work of interpretation of this material is incumbent upon researchers to historically contextualize the material and be transparent about its uses (Subotić 2020). In the appendix we describe in the detail how this archival material was collected and processed. We followed the advice of Balcells and Sullivan on best practices for generating and analyzing data from conflict archives.

\subsection{The Foundations of Social Cohesion and Conflict in Arab Palestinian Vil- lages}

Arab Palestinian villages in the late Mandate Palestine period, many rural and somewhat disconnected from their larger surroundings, were the center of life throughout this period. Most villages were centered around the extended family, often called clan, or hamula. Most villages had several different hamulas, and marriages frequently occurred within a hamula, or within the village. In Artas, an Arab Palestinian village near Bethlehem, in 1944, over seventy percent of marriages occurred within the village (Miller 1975). Morris refers to the villages as "autarchic or semi-autarchic" (Morris 2004, pg. 109). 
While clans tended to be homogeneous in terms of religion or ethnicity, many villages included hamulas from divergent backgrounds. In many villages, prominent hamulas engaged in perennial feuds with each other. In extreme cases, these rivalries devolved into cycles of killings and reprisals.

Furthermore, opposing national Palestinian movements competed to court loyalty and support at the hamula level. This often led to divisions along clan lines, with rival hamulas supporting opposing national political parties. The British colonial government exerted authority at the local level through traditional village structures. The changing relationship with the British authorities required the village to arrive at a consensus, but this was often challenged from within the village since often "conflict was as permanent as agreement in the dynamic village society" (Miller 1975, pg. 66).

\section{Research Design and Data}

We interrogate the argument empirically using village-level data from the 1948 War in Mandate Palestine. We conduct a cross-sectional analysis on the sample of Arab Palestinian villages in Mandate Palestine, fitting a logit model to regress the village's ultimate evacuation outcome on pre-war indicators of social cohesion and potential confounders. The full sample includes 249 villages: restricted to those included in the Village Files, excluding the West Bank and Gaza. In our main models including covariate adjustment for potential confounders, we further restrict analysis to the 218 villages for which we have sufficient information to measure key covariates. Below, we discuss the representativeness of the sample and discuss the limitations to confidence in the inferences drawn, given patterns of missing data.

\subsection{Village evacuation data}

We measure community evacuation outcomes using data from the Atlas of Palestine (Abu-Sitta 2004), which combines historical accounts by Morris (1987) and Khalidi and Elmusa (1992). ${ }^{5}$ We operationalize the distinction between preemptive and violent evacuation by drawing upon the six distinct proximate causes of village evacuation enumerated in Morris (1987):

- Expulsion by Jewish Forces;

- Military assault on the settlement by Jewish troops;

- Abandonment on Arab Orders;

- Fear of Jewish attack or of being caught up in the fighting;

${ }^{5}$ Morris used Israeli archives, while Khalidi's accounts come from the Palestine Index Gazeteer's list of villages. 


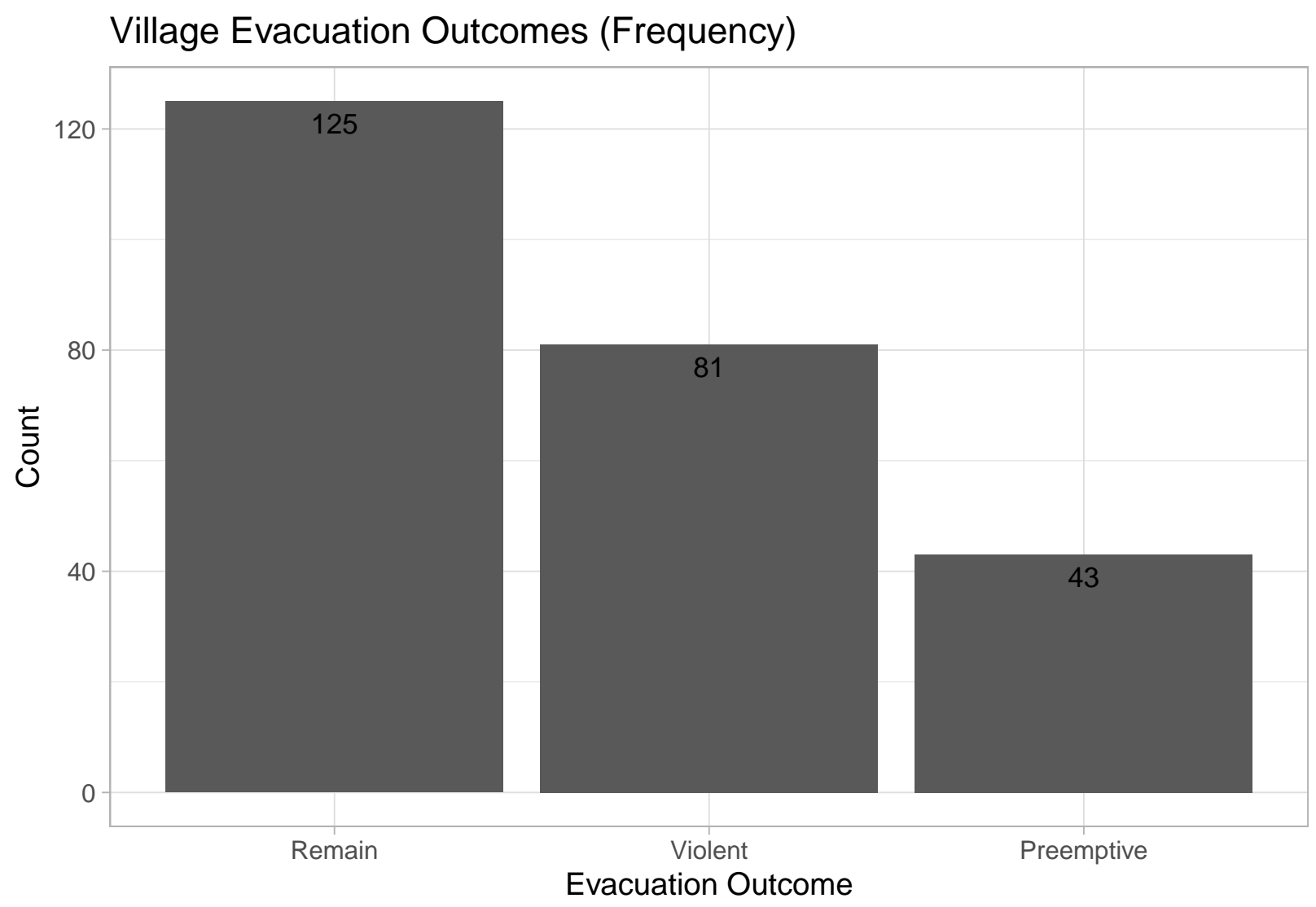

Figure 4: This figure shows the frequency of our three displacement outcomes: no evacuation (remain), violent evacuation, or preemptive evacuation. 
- "Whispering" campaigns; ${ }^{6}$

- Influence of fall of, or exodus from, neighboring town.

The first two types attribute the proximate cause of village evacuation to direct military-perpetrated violence, and so are considered violent. The remainder still involve coercion, including the threat of violence, but not yet its active deployment. We therefore consider these as preemptive evacuation. Including villages that 3) remain populated (at least partially), we observe three distinct evacuation outcomes. Figure 4 illustrates the distribution of the evacuation outcome across Arab Palestinian villages included in the sample.

\subsection{Village Social Cohesion Data}

The Village Files include information at the hamula level; indicating political loyalties, number of members, and the existence of rivalries and blood feuds between them. This detailed and systematic information allows for the construction of a measure of social cohesion based on distributive elements and relationships between primary social units within a village.

In addition, the Village Files also record a number of potential military attributes of the village, which we use as controls. For example, the reports specify the number of military aged men, and whether firearms are present in the village. We use these as indicators for the communities' perceived efficacy to militarily engage the Israeli belligerents.

The main measure of social cohesion we use in the analysis is a composite of three binary variables extracted from the Village Files. The first variable indicates whether community members are unified in support of one of the competing factions vying to represent the Palestinian national movement; the factions were lead by the Husseini and Nashashibi clans, respectively. This variable takes a value of 0 if at least one hamula in the village is affiliated with the Nashashibi, and at least one is affiliated with the Husseini faction. It takes a value of 1 if each hamula supports the same faction, or is unaffiliated with any political party. Villages in which the hamulas support different factions of the Palestinian national movement are plagued by infighting related to alignments with, and patronage from, competing national elites. By contrast, villages in which the hamulas are politically united on the national political cleavage enjoy greater social cohesion through common cause.

The second variable captures whether there exists intra-community conflict between hamulas in the village. The Village Files record the existence of "rivalry" and "blood feuds" between hamulas. Villages with active, or recent histories of, inter-clan rivalry or blood feuds clearly suffer high barriers to cooperation,

\footnotetext{
${ }^{6}$ The whispering campaigns refer a tactic in which the Jewish forces spread rumors among Arab villages about their military advances and brutality, to scare locals into preemptive collective exit.
} 


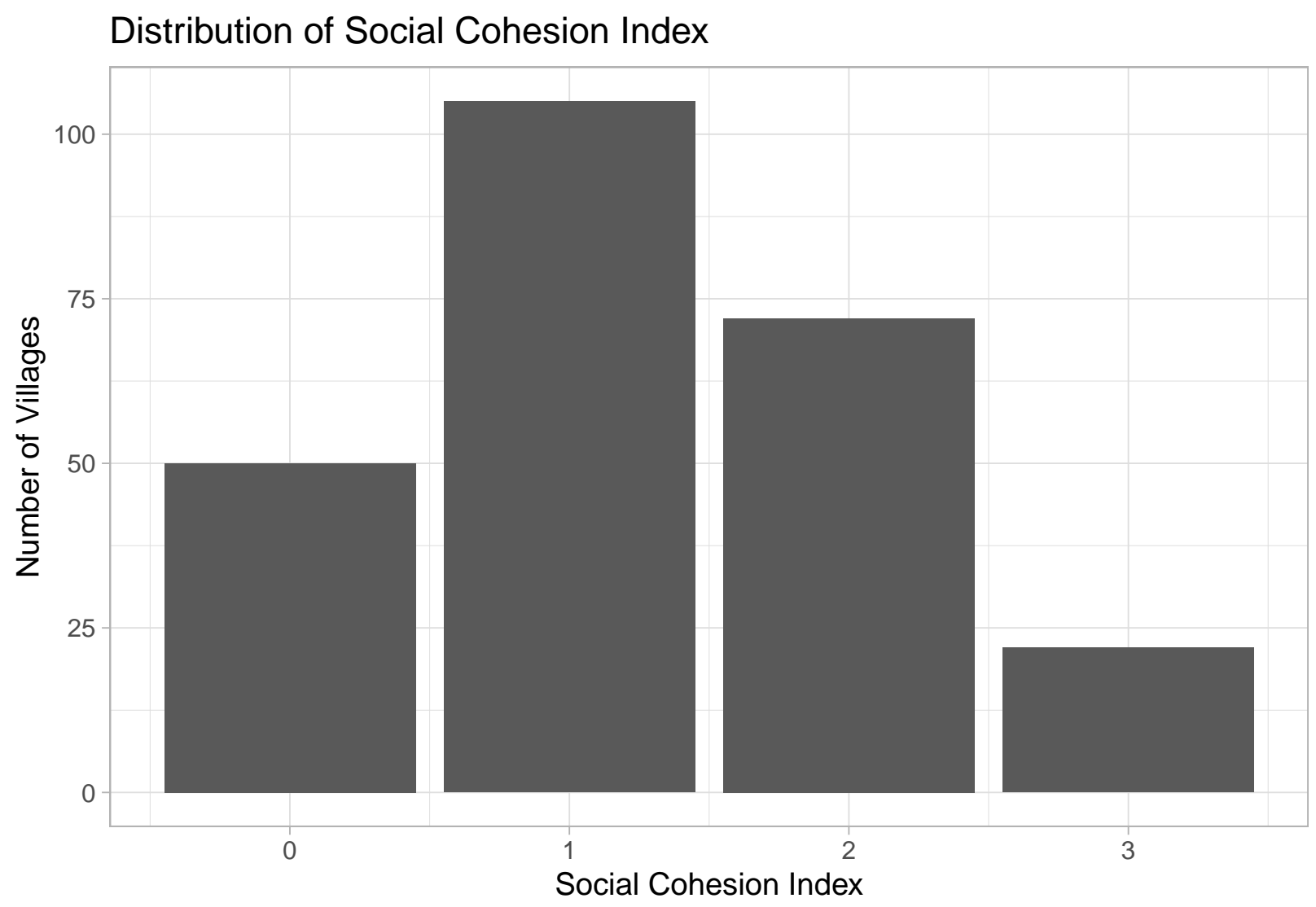

Figure 5: This figure shows the distribution of the additive social cohesion index across villages in the observed sample. 
and strong incentive to compete, across clan lines. Furthermore, community members may harbor negative attitudes towards the community as a whole relative to attitudes toward the parochial hamula social group. The variable takes a value of 0 if the village file records the existence of either a rivalry or blood feud, and 1 if not.

The third variable draws upon a measure of the "effective number" of hamulas. Specifically, we require a measure that incorporates not only the number of distinct hamulas in the village but also their relative sizes with respect to one another. To see why this is important, consider two sylized villages each with two hamulas. In Village A, humalas A.1 and A.2 both have 100 members. In village B, hamula B.1 has 100 members but B.2 has only 25 members. Whereas in A we may say there are 2 hamulas that influence collective decision-making, in village B we may find that the significantly larger hamula B.1 drives much of the village decision-making and the smaller B.2 must follow.

We adopt the Laakso-Taagepera (L-T) index (Laakso and Taagepera 1979) to summarize the effective number $(N)$ of hamulas using the following formula:

$$
N=\frac{1}{\sum_{i=1}^{n} p_{i}^{2}}
$$

where $n$ represents the number of hamulas in the village and $p_{i}$ representing hamula $i$ 's population as a proportion of the population including all hamulas. When the effective number of hamulas as measured by the L-T index is low (close to 1), social cohesion is higher. Villages with more hamulas face higher barriers to social cohesion and collective action tha nthose with fewer hamulas, each having a more broad-based membership. To convert this continuous measure to a binary variable for inclusion in the additive index of social cohesion, the variable takes a value of 1 if the effective number of hamulas is less than 2 , which is the median number of hamulas in the sample (in addition to making intuitive sense to capture social division within the community). Figure 5 shows the distribution of our index of social cohesion across villages.

\subsection{Confounding Variables}

We also collected data on a number of other village covariates to control for pre-treatment differences across villages that may affect confound our estimates of the effect of social cohesion on evacuation outcomes. First, we control for village population, using data from the 1945 British census. As we argue above, collective action on the scale necessary for preemptive evacuation becomes increasingly difficult with the number of people to mobilize, and introduces greater barriers to social cohesion. Furthermore, we argue that the effect of social cohesion should be moderated by village population. We include village population as a confounder in the naive model fits, and subsequently interact with social cohesion to explore the conditional effect proposed. 
To capture spatial variation in proximity to violence, to Jewish villages, and other geographic factors that cluster in space, we control for the latitude and longitude of the village. The Israelis prioritized villages located on hills for conquest in order to secure a strategic outpost. We use the log of the village's elevation from the Atlas of Palestine (Abu-Sitta 2004) to capture variation in a village's strategic location during the war. We also control for the log of the land area of the village, since geographic size may affect their likelihood of being targeted as well as the barriers to communication and coordination essential to social cohesion. Lastly, to control for the value of immovable assets, we control for the area within a village dedicated to citrus and banana orchards, since this was a main source of income for many Arab Palestinian communities.

\subsection{Which villages enter into the sample?}

The Haganah did not survey all villages in Mandate Palestine. The goal of the surveys was to collect important data about each village for strategic purposes, making it unlikely that the villages were randomly selected to be surveyed. To investigate how this non-random selection into the sample may affect our later estimates, we describe how the villages that are in the survey may differ from villages where no survey was conducted. Doing this requires information on villages that were not surveyed. We use the 1945 British Village Census to create a list of villages comprising the total sample, along with relevant covariates. This results in data on 789 villages.

Figure 6 illustrates the geographic distribution of villages included and excluded from the sample of Village Files, and Figure 7 compares the distribution on key covariates across these groups of villages. For most variables, the density plots are roughly similar across the different types of villages. The main difference lies in the distributions of the population variables. This is to be expected. Whether a village was a primarily Jewish or Arab village was well known and easily observable in Mandate Palestine. The Haganah had little reason to issue surveys to villages with a substantial Jewish population, since their coethnics would likely provide valuable intelligence and cooperation during any potential military conflict. The main perceived threat to the Haganah were Arab villages since they would be the main villages targeted in a conflict. Moreover, the different population distributions across villages with and without a survey likely has no impact on our analysis of village evacuation since during the 1948 War the only villages that the Israeli forces targeted for conquest were Arab villages. 
Arab Palestinian Villages Included in the Village Files

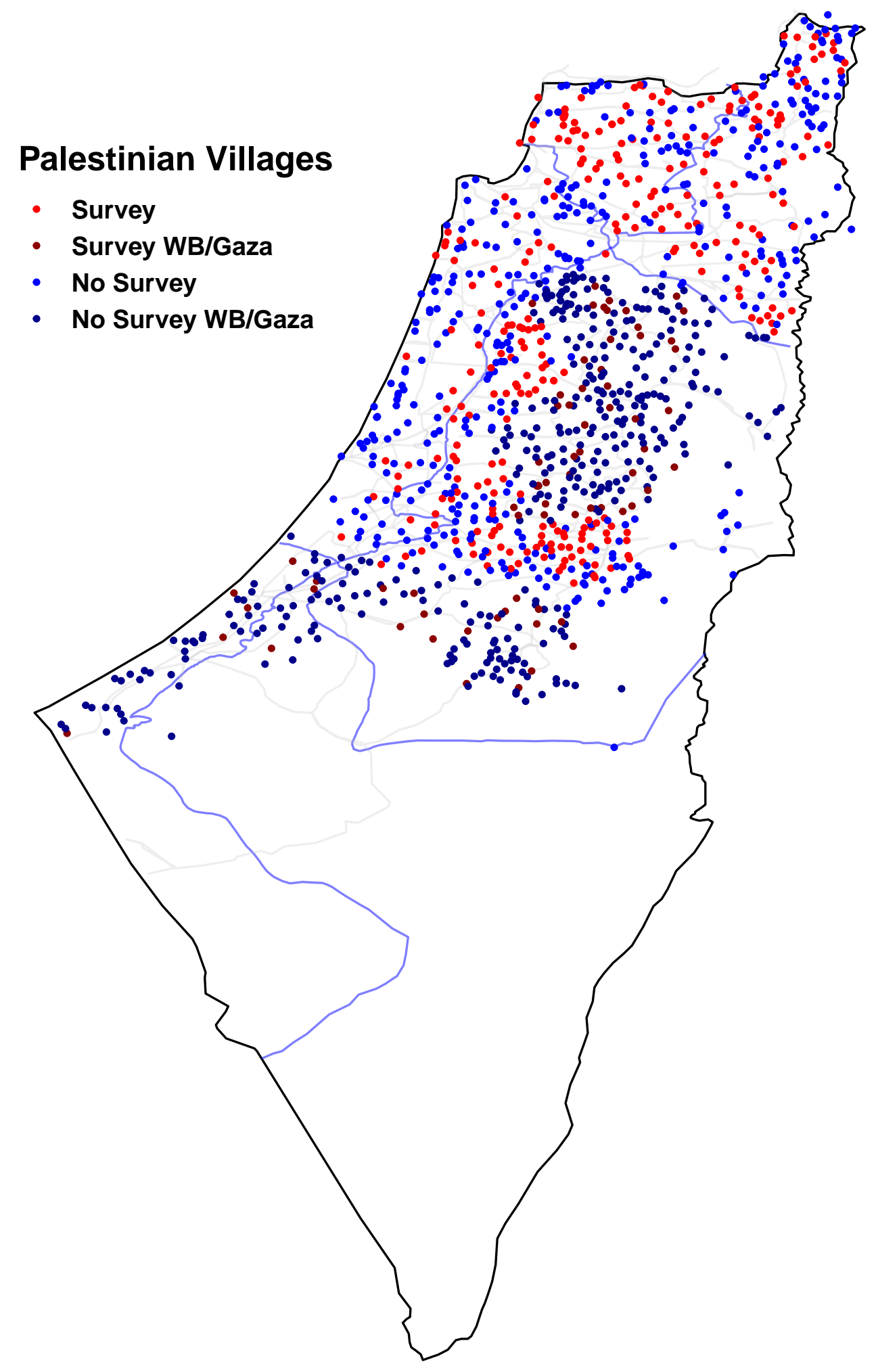

Figure 6: This map shows the location of villages along with whether a Village Survey was conducted, and whether they are located in the current West Bâk /Gaza area (excluding all villages in the Jerusalem district). 
Figure 7: Balance Plot

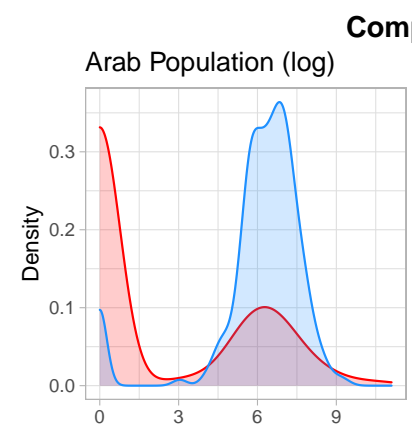

Comparison of Variables Between Villages With and Without a Survey
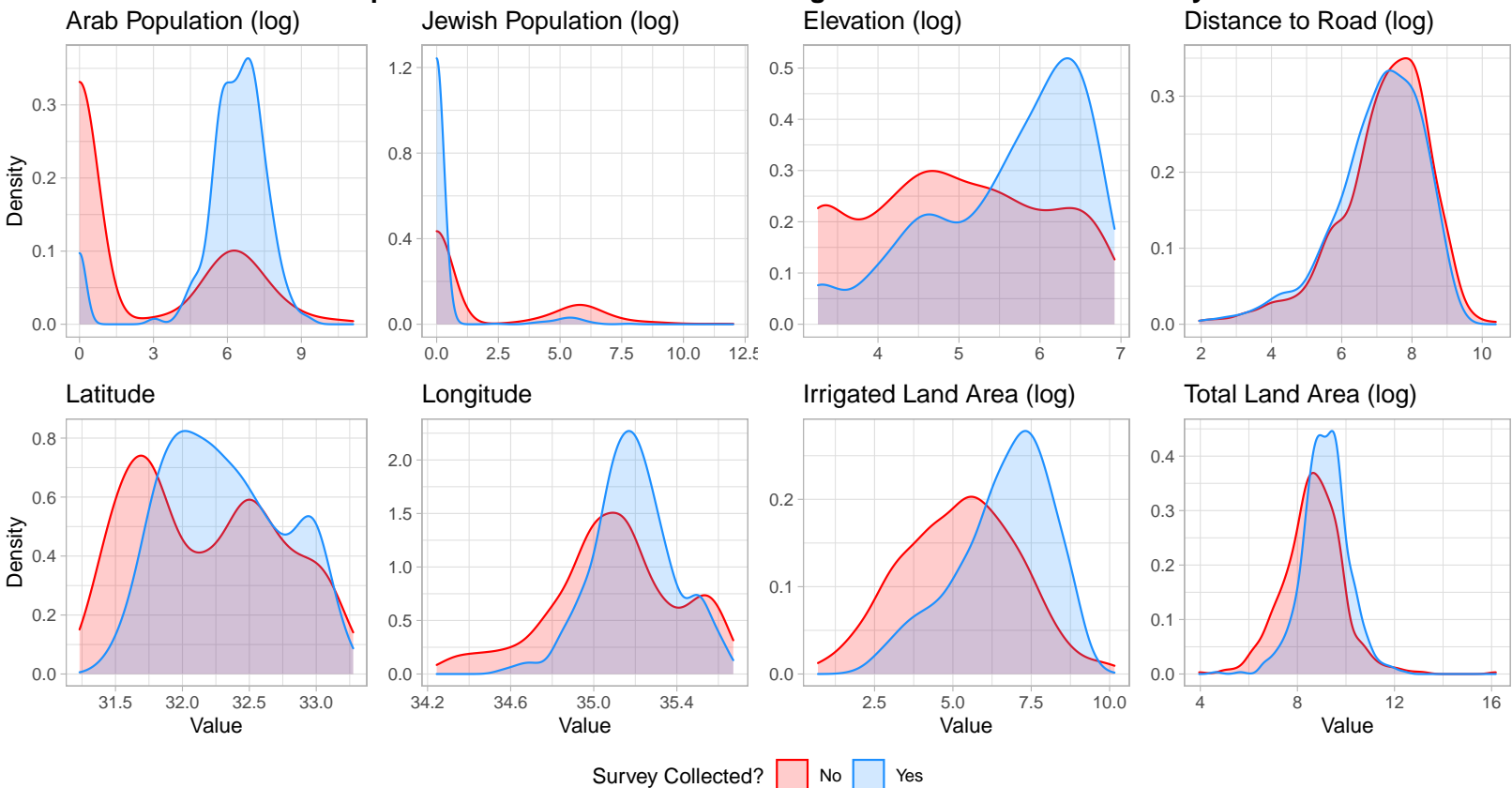

Survey Collected? $\square$ No $\square$ Yes

\section{$5 \quad$ Findings}

\subsection{Cross-Sectional Logit Model Results}

The bivariate relationship between evacuation outcomes and community social cohesion in the data is broadly consistent with the argument. As Figure 8 shows, among villages that preemptively evacuated, those with higher social higher values of social cohesion are over-represented by a wide margin.

Because the bivariate relationship may be confounded by additional factors that correlate with both cohesion and displacement processes, we present results from cross-sectional multivariate analysis to interrogate whether the relationship is robust to covariate adjustment for potential confounders. We fit a set of logit models in which the dependent variable is whether a village is preemptively evacuated. The results are summarized in Table 1.

Model 1 fits the naive bivariate relationship, regressing preemptive evacuation on the social cohesion index. Model 2 includes covariate adjustment for geographic location (latitude and longitude from the Atlas of Palestine) and village population. Model 3 includes additional controls for mean elevation, total land area, and cultivable land area. Model 4 includes an interaction between social cohesion and village population, following the hypothesis that the positive relationship between social cohesion and preemptive evacuation does not operate in small villages, and becomes more important as village population increases.

A close reading of the results shows the coefficient estimates on the social cohesion index are consistent 


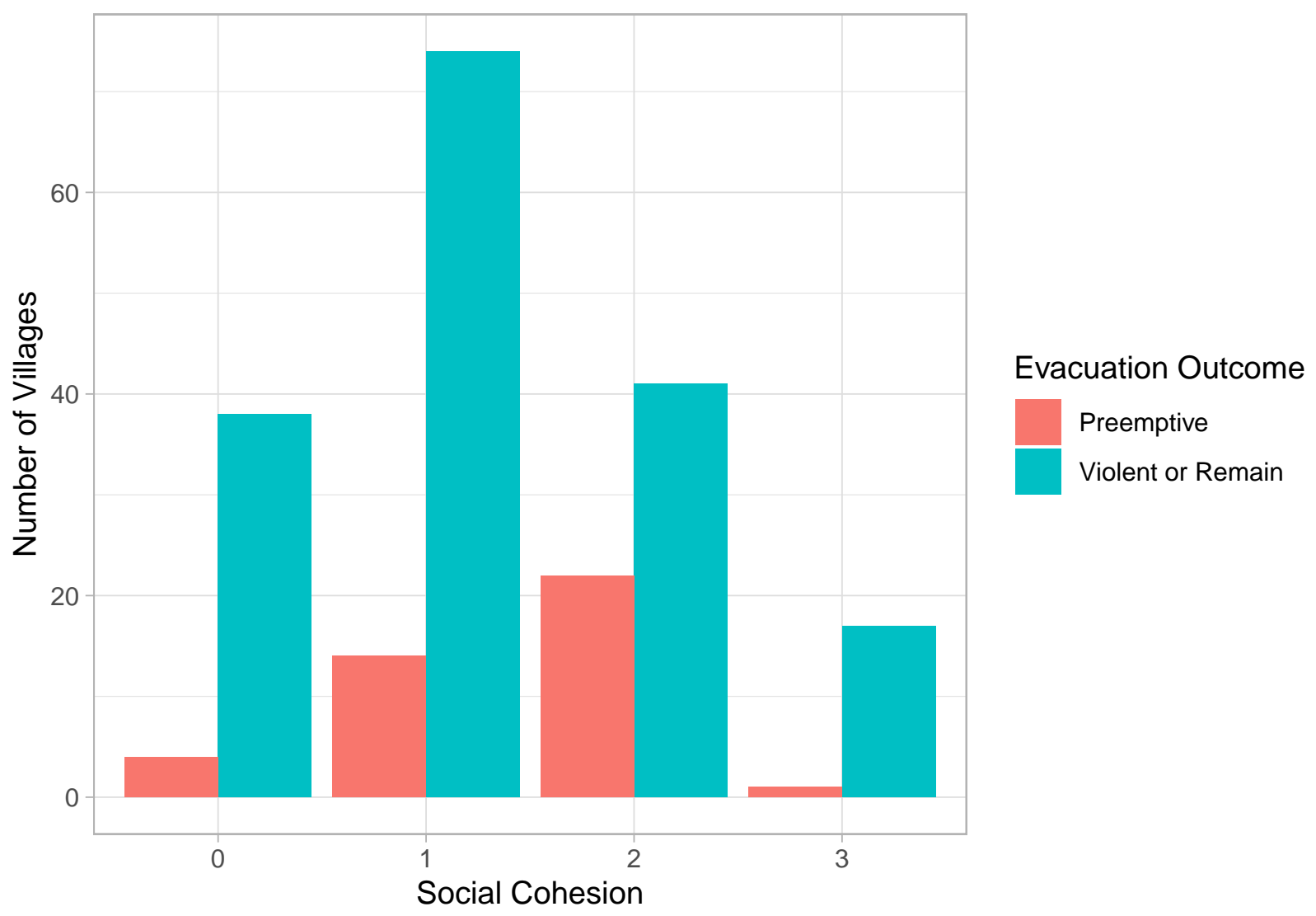

Figure 8: This figure shows the evacuation outcomes for the villages in our sample across different values of social cohesion. 
Table 1:

\begin{tabular}{|c|c|c|c|c|c|c|}
\hline & \multicolumn{6}{|c|}{ Dependent variable: } \\
\hline & \multicolumn{6}{|c|}{ Preemptive Evacuation } \\
\hline & \multicolumn{4}{|c|}{ logistic } & \multicolumn{2}{|c|}{$\begin{array}{c}\text { spatial } \\
\text { autoregressive }\end{array}$} \\
\hline & $(1)$ & $(2)$ & $(3)$ & $(4)$ & $(5)$ & $(6)$ \\
\hline Social Cohesion & $\begin{array}{l}0.346^{*} \\
(0.191)\end{array}$ & $\begin{array}{c}0.216 \\
(0.208)\end{array}$ & $\begin{array}{c}0.419 \\
(0.273)\end{array}$ & $\begin{array}{c}-5.244^{* *} \\
(2.297)\end{array}$ & $\begin{array}{c}0.032 \\
(0.029)\end{array}$ & $\begin{array}{c}-0.514^{* * *} \\
(0.188)\end{array}$ \\
\hline Latitude & & $\begin{array}{l}-0.525 \\
(0.511)\end{array}$ & $\begin{array}{c}-3.467^{* * *} \\
(0.951)\end{array}$ & $\begin{array}{c}-3.350^{* * *} \\
(0.955)\end{array}$ & & \\
\hline Longitude & & $\begin{array}{c}3.736^{* * *} \\
(1.176)\end{array}$ & $\begin{array}{c}9.505^{* * *} \\
(1.940)\end{array}$ & $\begin{array}{c}9.183^{* * *} \\
(1.973)\end{array}$ & & \\
\hline Village Pop & & $\begin{array}{l}-0.008 \\
(0.195)\end{array}$ & $\begin{array}{c}0.045 \\
(0.272)\end{array}$ & $\begin{array}{c}-1.163^{* *} \\
(0.560)\end{array}$ & $\begin{array}{l}-0.034 \\
(0.030)\end{array}$ & $\begin{array}{c}-0.137^{\text {*** }} \\
(0.046)\end{array}$ \\
\hline Mean Elevation & & & $\begin{array}{c}-1.652^{* * *} \\
(0.354)\end{array}$ & $\begin{array}{c}-1.652^{* * *} \\
(0.357)\end{array}$ & $\begin{array}{c}-0.051^{* *} \\
(0.026)\end{array}$ & $\begin{array}{c}-0.056^{* *} \\
(0.025)\end{array}$ \\
\hline Land Area & & & $\begin{array}{c}0.098 \\
(0.275)\end{array}$ & $\begin{array}{c}0.065 \\
(0.281)\end{array}$ & $\begin{array}{c}0.015 \\
(0.031)\end{array}$ & $\begin{array}{c}0.012 \\
(0.031)\end{array}$ \\
\hline Total Cultivatable Land & & & $\begin{array}{l}-0.114 \\
(0.303)\end{array}$ & $\begin{array}{l}-0.182 \\
(0.312)\end{array}$ & $\begin{array}{c}0.003 \\
(0.034)\end{array}$ & $\begin{array}{l}-0.015 \\
(0.034)\end{array}$ \\
\hline Social Cohesion * Village Pop & & & & $\begin{array}{l}0.880^{* *} \\
(0.352)\end{array}$ & & $\begin{array}{c}0.083^{* * *} \\
(0.028)\end{array}$ \\
\hline Observations & 249 & 247 & 218 & 218 & 218 & 218 \\
\hline $\begin{array}{l}\text { Log Likelihood } \\
\sigma^{2}\end{array}$ & -112.909 & -105.132 & -76.441 & -72.606 & $\begin{array}{c}-78.823 \\
0.116\end{array}$ & $\begin{array}{c}-74.594 \\
0.112\end{array}$ \\
\hline Akaike Inf. Crit. & 229.818 & 220.264 & 168.881 & 163.211 & 173.646 & 167.188 \\
\hline Wald Test $(\mathrm{df}=1)$ & & & & & $24.814^{* * *}$ & $25.140^{* * *}$ \\
\hline LR Test $(\mathrm{df}=1)$ & & & & & $21.099^{* * *}$ & $21.424^{* * *}$ \\
\hline
\end{tabular}


with the theory's empirical implications across models, which suggests community social cohesion should increase the likelihood of preemptive evacuation among Arab Palestinian villages during the 1948 War. In Models 1-3, the coefficient estimates on social cohesion are positive, but statistically indistinguishable from 0 in Models 2-3. The relationship appears weaker in these models for two reasons. First, they assume linearity in the effects of geographic position and village population. Second, and more importantly, the argument suggests a conditional effect of social cohesion moderated by population size. Villages with a smaller population face much lower barriers to engaging in collective action, as there are fewer actors to coordinate and fewer veto points. Among larger villages, the ability for a village to engage in collective action should vary considerably with social cohesion. When social cohesion is low, it is exceedingly difficult for the village to coordinate their behavior due to the large number of actors. Collective action on the scale necessary for preemptive evacuation should only occur when social cohesion is high.

The results in Model 4 support the proposed conditional effect. The coefficient estimate on social cohesion, representing its effect when village population is 0 (and therefore not substantively interpretable), is negative and statistically distinguishable from 0 . The coefficient on the interaction term is positive and statistically significant, suggesting cohesion increasingly promotes preemptive evacuation as population increases. Because the coefficient estimates are not informative beyond this general trend, we illustrate the conditional relationship in the marginal effects plot drawing upon Model 4. The results are displayed graphically in Figure 9. Consistent with our argument, the marginal effect of social cohesion on preemptive evacuation increases with the village size.

Models 5 and 6 fit spatial autoregressive models, regressing preemptive evacuation on the battery of covariates included in Models 3 and 4 (replacing latitude and longitude as covariates in the model), respectively. Spatial autogression takes into account that the outcome and predictor (explanatory variable) are spatially correlated, such that not all observations are independent. As Table 1 shows, the results are statistically very similar and substantively identical to the simpler non-spatial logit model.

\subsection{Additional Analyses and Robustness Checks}

We conduct a series of robustness checks on the main empirical tests to ensure the results are not sensitive to model specification. We fit alternative models including covariate adjustment for the area of Arab Palestinian-owned orchards, the number of military aged men, and the presence of firearms in the village from the Village Files. Next, we split the sample to investigate the relationship between preemptive evacuation and social cohesion among sufficiently populous villages, varying the threshold of village population used to split the sample. Across the analyses using a range of thresholds, the positive relationship between 


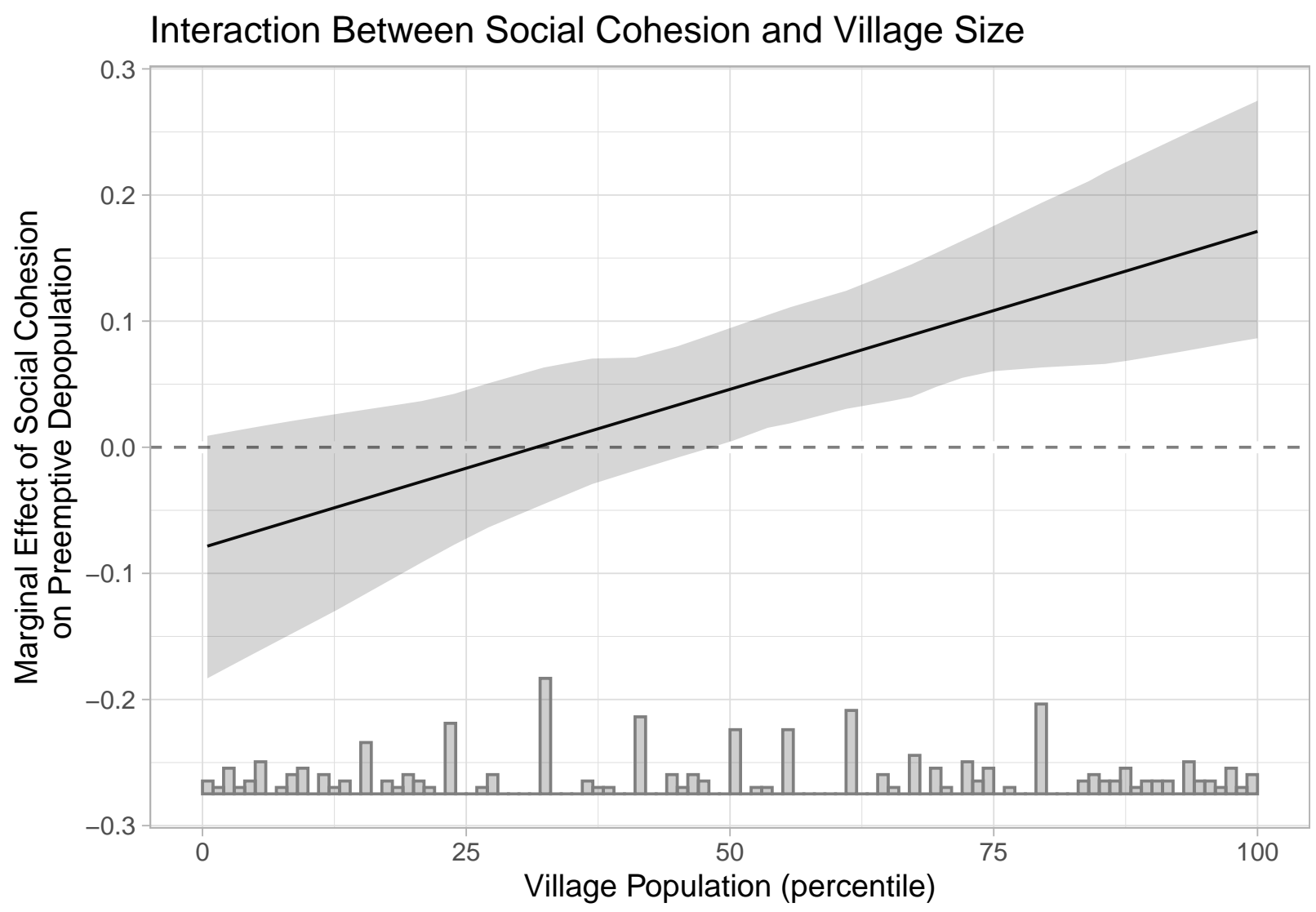

Figure 9: This plot shows the marginal effect of social cohesion on preemptive depopulation, moderated by the size of the village in terms of population. 
preemptive evacuation and community social cohesion remains among the higher-population subset when fitting the multivariate models. The full results are reported in the Appendix.

Furthermore, the argument implies social cohesion promotes preemptive, as opposed to violent, evacuation in the observed context of a strategic displacement campaign. One reason our argument is ambiguous in its implications for variation in violent evacuation is that in this context civilian agency to pursue autonomy strategies is extremely limited. Another reason is the sequencing: socially cohesive communities that are most likely to be exposed to violence strategically select into the preemptive evacuation outcome. To probe whether the evidence supports the theoretical mechanisms proposed here, rather than absorbing alternative mechanisms that relate social cohesion to evacuation, we perform a similar analysis in which the dependent variable is a binary indicator of violent evacuation, expecting null or weaker results for the correlation between social cohesion and violent evacuation.

The results are presented in Section C.1 in the Appendix. The coefficient estimates for social cohesion are substantively small and statistically indistinguishable from 0 . Together with the results from Table 1 , the cross-sectional analysis provides evidence consistent with the argument that social cohesion increases preemptive evacuation (relative to violent evacuation or remain), and that it does not increase violent evacuation (relative to preemptive evacuation or remain).

\section{Conclusion}

Communities face hard choices and severe constraints on their ability to protect themselves during wartime. Yet, as research on forced displacement has shown, civilians exercise agency to influence belligerent conduct and protect their communities even in context of widespread and intense civilian-targeted violence. Communities at a minimum retain some control over if, when, and how to flee their homes to escape violence, producing patterns of forced displacement in conflict contexts.

In this article, we explain variation in the process of displacement. We ask, why do some communities preemptively evacuate a village, while others remain, risking violent cleansing or depopulation? Previous literature has focused on conditions external to the community that shape civilian incentives, such as the level of violence, characteristics of the areas of potential refuge, political or economic material incentives to leave or remain, or identity affiliations with warring parties. We show that these explanations are incomplete, as they cannot account for observed local-level variation in evacuation outcomes across villages facing similar material incentives and constraints. Shifting focus to civilian agency and communities' social characteristics, we show that social cohesion plays a significant role in displacement processes. Specifically, at least among sufficiently populous villages, communities with higher social cohesion are more likely to 
facilitate a preemptive evacuation.

The empirical evidence draws upon unique data from a pre-war survey documenting social relationships between families within each village in a crucial case: the 1948 War in Mandate Palestine. The findings suggest that, even in the context of territorial conflict in which the belligerents adopted strategic displacement tactics, community social cohesion played a significant role in shaping whether communities preemptively evacuated prior to violence exposure. The Village Files, from which we measure our key predictor of social cohesion, draw upon uniquely detailed information from local informants to depict social, economic, political, and cultural features at the village level in the period just before the 1948 War. The level of detail in these documents provides essential insight into the pre-1948 social and economic conditions in Arab Palestinian villages that not only contributes to the historical record but also enables the systematic empirical investigation of social science theories related to conflict and displacement processes Morris (2004).

The findings have clear policy implications for war-affected communities. Strengthening ties and relationships within a community, across social cleavages, can mitigate some of the disastrous outcomes during war. Our work shows that this community-level work should be pursued primarily in larger communities, in states with a high risk of conflict emergence.

The present study has several limitations that motivate future research. First, the 1948 War is often considered unique, in a variety of ways related to the politics of the region and religious and ethno-nationalist cleavages. In the absence of national institutions and an organized military, Arab Palestinian communities lacked protection against advancing Israeli forces (strong incentives to flee) and the migration processes could not have been organized by national leadership. This provides the analytic leverage to isolate the role of community capabilities, but suggests additional research is needed to probe generalizability to other conflicts.

Second, Village Files were collected by one of the belligerents in the conflict, whose statebuilding efforts and political violence directly provoked the forced displacement among the villages observed. While the Shai used local informants and designed a system for systematic and detailed description of village conditions according to locals' perspective, we cannot ignore the political and power conditions that may have shaped patterns in access to informants and the veracity and representativeness of the information extracted from the villages. Readers must keep in mind the source of the information and future research may complement this analysis with alternative sources as they become available.

We also do not know exactly why some villages had higher levels of social cohesion, while some had lower levels. The historical literature is quite clear that the events during the 1936-1939 Arab Revolt against British Colonialism led to the fracturing of Arab Palestinian society, with some scholars arguing that this fractionalization enabled the Israeli forces' quick victory. Other explanations stress the importance of the 
political networks led by the Nashashibi and Husseini clans. We recognize that unobserved characteristics of the Arab Palestinian villages in our sample may confound the relationship between social cohesion and displacement outcomes.

Future research may disaggregate the components of social cohesion to investigate the distinct role of each of its component elements on community choices during war. How and which of these component elements have a specific effect on the constrained choices of communities? Furthermore, future research may integrate the belligerents' strategic considerations into the theoretical and empirical framework examined here, to map variation in the level of threat and community constraints as they vary locally within conflict zones and over time (determined, for example, by the proximity to belligerent attacks at a given time).

In this paper we focused primarily on what we called the pre-occupation phase to address the specific question about the role of social cohesion and its effect on the form of evacuation, but several questions remain. What factors affect the decision to stay? What differentiates communities forcibly evacuated from those that remained intact under the Israeli control after the war ended? How do the pre-conflict relationships between communities across conflict-related social cleavages (Jewish and Arab communities) impact civilians' migration decisions and the community-level outcomes? Lastly, whether and how to evacuate represents but one choice, albeit extreme, that communities face during war. Future research may examine evacuation alongside the broader repertoire of actions communities, and individual civilians, may adopt during conflict; including autonomy and resistance strategies addressed elsewhere and the diverse set of displacement processes other than full evacuation. 


\section{References}

Abbasi, Mustafa. 2019. "Before Their Exile: The Transformation of Palestininan Villages in Western Galilee, 1918-1948." Journal of Holy Land and Palestine Studies 18(1): 75-99.

Abu-Sitta, Salman H. 2004. Atlas of Palestine, 1948. Palestine Land Society.

Adhikari, Prakash. 2013. "Conflict-Induced Displacement, Understanding the Causes of Flight." American Journal of Political Science 57(1): 82-89.

Al-Hout, Bayan Nuweihid. 1979. "The Palestinian Political Elite During the Mandate Period." Journal of Palestine Studies 9(1): 85-111.

Arjona, Ana. 2016. Rebelocracy: Social Order in the Colombian Civil War. New York, NY: Cambridge University Press.

Balcells, Laia. 2010. "Rivalry and Revenge: Violence Against Civilians in Conventional Civil Wars." International Studies Quarterly 54(2): 291-313.

- 2017. Rivalry and Revenge. Cambridge University Press.

Balcells, Laia, and Christopher M Sullivan. 2018. "New Findings from Conflict Archives: An Introduction and Methodological Framework." Journal of Peace Research 55(2): 137-46.

Benvenisti, Meron. 2000. Sacred Landscape: The Buried History of the Holy Land Since 1948. Univ of California Press.

Camarena, Kara Ross. "Leaving as a Community: How Uncertainty and Group Dynamics Inform the Choice to Flee Violence."

Chwe, Michael Suk-Young. 1999. "Structure and Strategy in Collective Action." American journal of sociology 105(1): 128-56.

Cohen, Hillel. 2009. Army of Shadows: Palestinian Collaboration with Zionism, 1917-1948. Univ of California Press.

Czaika, Mathias, and Krisztina Kis-Katos. 2009. "Civil Conflict and Displacement: Village-Level Determinants of Forced Migration in Aceh." Journal of peace research 46(3): 399-418.

Davenport, Christina, Will Moore, and Steven Poe. 2003. "Sometimes You Just Have to Leave: Domestic Threats and Forced Migration, 1964-1989." International Interactions 29(1): 27-55.

Dorff, Cassy. 2017. "Violence, Kinship Networks, and Political Resilience: Evidence from Mexico." Journal of Peace Research 54(4): 558-73.

Engel, Stefanie, and Ana Maria Ibáñez. 2007. "Displacement Due to Violence in Colombia: A HouseholdLevel Analysis." Economic development and cultural change 55(2): 335-65.

Friedkin, Noah E. 2004. "Social Cohesion." Annual Review of Sociology 30: 409-25. 
Gade, Emily Kalah. 2020. "Social Isolation and Repertoires of Resistance." American Political Science Review: $1-17$.

Getmansky, Anna, Tolga Sinmazdemir, and Thomas Zeitzoff. 2018. "Refugees, Xenophobia, and Domestic Conflict: Evidence from a Survey Experiment in Turkey." Journal of Peace Research 55(4): 491-507.

Gould, Roger V. 1993. "Collective Action and Network Structure." American Sociological Review: 18296.

Hoffman, Bruce. 2016. Anonymous Soldiers: The Struggle for Israel, 1917-1947. Vintage.

Jackson, Matthew O, Tomas Rodriguez-Barraquer, and Xu Tan. 2012. "Social Capital and Social Quilts: Network Patterns of Favor Exchange." The American Economic Review 102(5): 1857-97.

Jawad, Saleh Abdel. 2016. "Colonial Anthropology: The Haganah Village Intelligence Archives." Jerusalem Quarterly (68): 21.

Kalyvas, Stathis. 2006. The Logic of Violence in Civil War. Cambridge University Press.

Kaplan, Oliver. 2017. Resisting War: How Communities Protect Themselves. Cambridge University Press.

Khalaf, Issa. 1991. Politics in Palestine: Arab Factionalism and Social Disintegration, 1939-1948. SUNY Press.

Khalidi, Walid, and Sharif S Elmusa. 1992. All That Remains: The Palestinian Villages Occupied and Depopulated by Israel in 1948. Inst for Palestine Studies.

Khalili, Laleh. 2004. "Grass-Roots Commemorations: Remembering the Land in the Camps of Lebanon." Journal of Palestine Studies 34(1): 6-22.

Krause, Jana. 2018. Resilient Communities: Non-Violence and Civilian Agency in Communal War. Cambridge University Press.

Laakso, Markku, and Rein Taagepera. 1979. “'Effective’ Number of Parties: A Measure with Application to West Europe." Comparative political studies 12(1): 3-27.

Larson, Jennifer M, and Janet I Lewis. 2018. "Rumors, Kinship Networks, and Rebel Group Formation." International Organization 72(4): 871-903.

Lewis, Janet I. 2017. "How Does Ethnic Rebellion Start?” Comparative Political Studies 50(10): 1420-50.

- 2020. How Insurgency Begins: Rebel Group Formation in Uganda and Beyond. Cambridge

University Press.

Lichtenheld, Adam G. 2020. "Explaining Population Displacement Strategies in Civil Wars: A CrossNational Analysis." International Organization 74(2): 253-94.

Lischer, Sarah Kenyon. 2007. "Causes and Consequences of Conflict-Induced Displacement." Civil Wars 9(2): 142-55. 
Luft, Aliza. 2020. "How Do You Repair a Broken World? Conflict (Ing) Archives After the Holocaust." Qualitative Sociology 43(3): 317-43.

Marston, Jerome F. 2020. "Resisting Displacement: Leveraging Interpersonal Ties to Remain Despite Criminal Violence in Medellin, Colombia." Comparative Political Studies: 0010414020912276.

Melander, Erik, and Magnus Öberg. 2006. "Time to Go? Duration Dependence in Forced Migration." International Interactions 32(2): 129-52.

Miller, Ylana N. 1975. "From Village to Nation: Government and Society in Rural Palestine, 1920-1948." ProQuest Dissertations 83 Theses A\&I.

Moore, Will H, and Stephen M Shellman. 2004. "Fear of Persecution: Forced Migration, 1952-1995." Journal of Conflict Resolution 48(5): 723-45.

—. 2006. "Refugee or Internally Displaced Person? To Where Should One Flee?" Comparative Political Studies 39(5): 599-622.

—. 2007. "Whither Will They Go? A Global Study of Refugees' Destinations, 1965-1995." International Studies Quarterly 51(4): 811-34.

Morris, Benny. 1987. 15 The Birth of the Palestinian Refugee Problem, 1947-1949. Cambridge [Cambridgeshire]; New York: Cambridge University Press.

- 2004. 1948: A History of the First Arab-Israeli War. Yale University Press, New Haven, CT.

Neumayer, Eric. 2004. "Asylum Destination Choice: What Makes Some West European Countries More Attractive Than Others?" European Union Politics 5(2): 155-80.

—. 2005a. "Asylum Recognition Rates in Western Europe: Their Determinants, Variation, and Lack of Convergence." Journal of conflict resolution 49(1): 43-66.

—. 2005b. "Bogus Refugees? The Determinants of Asylum Migration to Western Europe." International studies quarterly 49(3): 389-409.

Pappe, Ilan. 2007. The Ethnic Cleansing of Palestine. Oneworld Publications.

Pappé, Ilan. 2006. "The 1948 Ethnic Cleansing of Palestine." Journal of Palestine Studies 36(1): 6-20.

Pappé, Ilan. 2020. "An Indicative Archive: Salvaging Nakba Documents." Journal of Palestine Studies 49(3): $22-40$.

Parkinson, Sarah Elizabeth. 2013. "Organizing Rebellion: Rethinking High-Risk Mobilization and Social Networks in War." American Political Science Review 107(03): 418-32.

Pearlman, Wendy. 2011. Violence, Nonviolence, and the Palestinian National Movement. Cambridge University Press.

Petersen, Roger D. 2001. Resistance and Rebellion: Lessons from Eastern Europe. Cambridge University Press. 
Raz, Adam. 2021. "When Israel Placed Arabs in Ghettos Fenced by Barbed Wire." haaretz.com. https://www.haaretz.com/israel-news/.premium-when-israel-placed-arabs-in-ghettos-fenced-by-barbedwire-1.8877340.

Revkin, Mara. 2020. "Competitive Governance and Displacement Decisions Under Rebel Rule: Evidence from the Islamic State in Iraq." Journal of Conflict Resolution.

Rubin, Michael A. 2020. "Rebel Territorial Control and Civilian Collective Action in Civil War: Evidence from the Communist Insurgency in the Philippines." Journal of Conflict Resolution 64(2-3): 459-89.

Salomon, Shimri. 2010. "The Village Files Project, Part 2: 1945-1948." Haganah Quarterly Bulletin (2).

Schon, Justin. 2015. "Focus on the Forest, Not the Trees: A Changepoint Model of Forced Displacement." Journal of Refugee Studies 28(4): 437-67.

Schwartz, Stephanie. 2019. "Home, Again: Refugee Return and Post-Conflict Violence in Burundi." International Security 44(2): 110-45.

Sela, Rona. 2013. "Scouting Palestinian Territory, 1940-1948: Haganah Village Files, Aerial Photos, and Surveys." Jerusalem Quarterly (52).

Siegel, David A. 2009. "Social Networks and Collective Action." American Journal of Political Science 53(1): $122-38$.

Steele, Abbey. 2009. "Seeking Safety: Avoiding Displacement and Choosing Destinations in Civil Wars." Journal of Peace Research 46(3): 419-29.

— 2011. "Electing Displacement: Political Cleansing in Apartadó, Colombia." Journal of Conflict Resolution 55(3): 423-45.

—. 2017. Democracy and Displacement in Colombia's Civil War. Cornell University Press.

—. 2019. "Civilian Resettlement Patterns in Civil War." Journal of peace research 56(1): 28-41.

Subotić, Jelena. 2020. "Ethics of Archival Research on Political Violence." Journal of Peace Research: 0022343319898735 .

Tal, David. 2004. War in Palestine, 1948: Israeli and Arab Strategy and Diplomacy. Routledge.

Wimmer, Andreas, and Chris Miner. 2020. "The Strategic Logic of Ethnoterritorial Competition: Violence Against Civilians in Africa's Civil Wars." Journal of Global Security Studies 5(3): 389-407.

Wood, Reed M. 2010. "Rebel Capability and Strategic Violence Against Civilians." Journal of Peace Research 47(5): 601-14.

—. 2014. "Opportunities to Kill or Incentives for Restraint? Rebel Capabilities, the Origins of Support, and Civilian Victimization in Civil War." Conflict Management and Peace Science 31(5): 461-80.

Woolcock, Michael, and Deepa Narayan. 2000. "Social Capital: Implications for Development Theory, Research, and Policy." The world bank research observer 15(2): 225-49. 
Zhukov, Yuri M. 2015. "Population Resettlement in War: Theory and Evidence from Soviet Archives." Journal of Conflict Resolution 59(7): 1155-85. 